\title{
HOW LONG DOES EVOLUTION OF THE TROGLOMORPHIC FORM TAKE? ESTIMATING DIVERGENCE TIMES IN ASTYANAX MEXICANUS
}

\author{
KAKO DOLGO TRAJA EVOLUCIJA TROGLOMORFNIH OBLIK? \\ OCENJEVANJE DIVERGENČNIH ČASOV PRI ASTYANAX \\ MEXICANUS
}

\author{
Megan L. PORTER ${ }^{1}$, Katharina DITTMAR ${ }^{2}$ \& Marcos PÉREZ-LOSADA ${ }^{3}$
}

\begin{abstract}
UDC 551.44:597

591.542

Megan L. Porter, Katharina Dittmar \& Marcos Pérez-Losada: How long does evolution of the troglomorphic form take? Estimating divergence times in Astyanax mexicanus

Features including colonization routes (stream capture) and the existence of both epigean and cave-adapted hypogean populations make Astyanax mexicanus an attractive system for investigating the subterranean evolutionary time necessary for acquisition of the troglomorphic form. Using published sequences, we have estimated divergence times for A. mexicanus using: 1) two different population-level mitochondrial datasets (cytochrome $\mathrm{b}$ and NADH dehydrogenase 2) with both strict and relaxed molecular clock methods, and 2) broad phylogenetic approaches combining fossil calibrations and with four nuclear (recombination activating gene, seven in absentia, forkhead, and $\alpha$-tropomyosin) and two mitochondrial (16S rDNA and cytochrome b) genes. Using these datasets, we have estimated divergence times for three events in the evolutionary history of troglomorphic A. mexicanus populations. First, divergence among cave haplotypes occurred in the Pleistocene, possibly correlating with fluctuating water levels allowing the colonization and subsequent isolation of new subterranean habitats. Second, in one lineage, A. mexicanus cave populations experienced introgressive hybridization events with recent surface populations (0.26-2.0 Ma), possibly also correlated with Pleistocene events. Finally, using divergence times from surface populations in the lineage without evidence of introgression as an estimate, the acquisition of the troglomorphic form in A. mexicanus is younger than 2.2 (fossil calibration estimates) - 5.2 (cytb estimate) Ma (Pliocene).
\end{abstract}

Key words: Astyanax mexicanus, divergence time, troglomorphy, subterranean, evolution.
Izvleček

UDK 551.44:597

591.542

Megan L. Porter, Katharina Dittmar \& Marcos Pérez-Losada: Kako dolgo traja evolucija troglomorfnih oblik? Ocenjevanje divergenčnih časov pri Astyanax mexicanus

Značilnosti, ki vključujejo tudi kolonizacijske poti in obstoj tako epigejičnih kot hipogejičnih populacij vrste Astyanax mexicanus, ji omogočajo, da predstavlja zanimiv sistem za proučevanje evolucije in časa, potrebnega za razvoj podzemeljskih troglomorfnih oblik. Za A. mexicanus smo na podlagi že objavljenih sekvenc ocenili divergenčni čas ob uporabi: 1) dveh različnih populacijskih mitohondrialnih podatkovnih baz (citokrom $\mathrm{b}$ in NADH dehidrogenaze 2), obe $\mathrm{z}$ natančno in sproščeno metodo molekularne ure, in 2) razširjenega filogenetskega pristopa $\mathrm{v}$ kombinaciji s fosilno kalibracijo ter štirimi jedrnimi geni (rekombinacijski aktivacijski gen, "forkhead kontrolni gen" in $\alpha$-tropomiozin) in dvema mitohondrialnima genoma (16S rDNA in citokrom b). Ob uporabi navedenih podatkovnih baz smo ocenili divergenčni čas za tri dogodke v zgodovini razvoja troglomorfnih populacij A. mexicanus. Prvič, razhajanje med podzemeljskimi haplotipi se je zgodilo v Pleistocenu, verjetno v odvisnosti od nihanja vode, ki je omogočilo kolonizacijo in posledično izolacijo v novih podzemeljskih habitatih. Drugič, verjetno je $\mathrm{v}$ povezavi s pleistocenskimi dogodki pri eni liniji podzemeljskih populacij $A$. mexicanus prišlo do introgresivne hibridizacije s takratnimi površinskimi populacijami $(0.26-2.0$ Ma). Z uporabo divergenčnega časa površinskih populacij tistih linij, ki ne kažejo introgresije ocenjujemo, da je troglomorfna oblika A. mexicanus mlajša od 2,2 (ocene fosilne kalibracije) do 5,2 milijona let (cytb ocena) (Pliocen).

Ključne besede: Astyanax mexicanus, divergenčni čas, troglomorfizem, podzemlje, speleobiologija, evolucija.

\footnotetext{
${ }^{1}$ Dept. of Biological Sciences, University of Maryland Baltimore County, Baltimore, MD, USA; e-mail: porter@umbc.edu

${ }^{2}$ Dept. of Molecular Biology, University of Wyoming, Laramie, WY, USA

${ }^{3}$ GENOMA LLC, 50E Woodland Hills, Provo, UT 84653-2052, USA
}

Received/Prejeto: 06.12.2006 


\section{INTRODUCTION}

Understanding the evolution of the cave form has fascinated biologists interested in subterranean faunas since Darwin. Termed 'troglomorphy', the suite of progressive and regressive characters associated with cavernicolous animals can be observed in the worldwide convergence of form found in the cave environment, exhibited in similar structural, functional, and behavioral changes across diverse taxonomic groups. Much of the debate over troglomorphy has centered on the evolutionary mechanisms responsible for character regression, generally argued to be either neutral mutation or natural selection. Several studies, (Gammarus minus - Culver et al., 1995; Astyanax mexicanus - Jeffery, 2005) have shown eye degeneration is the result of selection, and, in the case of $A$. mexicanus, is caused by the pleiotropic effects of natural selection for constructive traits. Another, less studied, aspect of understanding troglomorphy is the evolutionary time required to gain the cave form. Because it is generally difficult to pinpoint the time of subterranean colonization and isolation from surface ancestors, few troglomorphic species offer the opportunity for quantitative estimates of the evolutionary time spent in the subterranean realm. Therefore, the time of cave adaptation is thought of in relative terms, where the degree of eye and pigment reduction indicates the period of cavernicolous evolution and therefore the relative phylogenetic age of each species (Aden, 2005).

In evolutionary studies of cave adaptation, Astyanax mexicanus has become a model system (Jeffery, 2001). The advantageous features of $A$. mexicanus as a model system include the existence of both surface and troglomorphic cavefish populations, with several cave fish populations having evolved constructive and regressive changes independently (Jeffery, 2001). Furthermore, since the discovery of the species in 1936 (Hubbs \& Innes, 1936), there has been an extensive amount of research devoted to characterizing developmental, phylogenetic, taxonomic, and biogeographic aspects of the species (Jeffery, 2001; Mitchell et al., 1977; Wiley \& Mitchell, 1971;). In terms of being a model system for understanding the evolution of the troglomorphic form, A. mexicanus has at least one additional favorable attribute. The primary mode of $A$. mexicanus subterranean colonization is via stream capture, with most of the captured surface drainages no longer supporting epigean populations (Mitchell et al., 1977). These captures provide discrete colonization events correlated with divergence time from surface populations and therefore with the time of subterranean evolution.

Molecular studies that have looked at A. mexicanus phylogeography indicate that at least two independent invasions of surface Astyanax have occurred (Dowling et al., 2002a; Strecker et al., 2003, 2004). These two distinct A. mexicanus genetic lineages consist of cave fish from La Cueva Chica, La Cueva de El Pachón, El Sótano de Yerbaniz, El Sótano de Molino, El Sótano de Pichijumo, and La Cueva del Río Subterráneo (lineage A) and from La Cueva de los Sabinos, El Sótano de la Tinaja, La Cueva de la Curva, and El Sótano de Las Piedras (Lineage B) with different evolutionary histories - Lineage A clusters with closely related epigean populations while lineage B has no closely related epigean counterparts. The close association of Lineage A to epigean populations (as estimated by mitochondrial markers) is thought to be the result of either recent subterranean colonization or reflect recent introgressive hybridization with surface populations, while lineage $\mathrm{B}$ is considered to be a more ancient colonization event from surface populations that are extinct in the region (Dowling et al., 2002a; Strecker et al., 2004). Although the evolutionary histories of different hypogean A. mexicanus populations are complex, the two lineages offer the unique opportunity to estimate the divergence time required for the evolution of the troglomorphic form based on discrete times of colonization and the previous molecular studies of their phylogeography. At least one other study has estimated lineage ages in A. mexicanus populations; however, this study was based on a single gene molecular clock estimate and did not specifically estimate the divergence times of the cave populations (Strecker et al., 2003). Here we use three different sets of publicly available sequence data and known fossil calibrations and apply multiple phylogenetic approaches to estimate the age of cave colonization and stream capture events, and to provide an estimate of the time necessary to acquire the troglomorphic form in $A$. mexicanus. 


\section{METHODS}

\section{Sequence Data}

Data were acquired from Genbank (http://www.ncbi. nlm.nih.gov/) from previously published studies of $A$. mexicanus and characiform fishes (Tab. 1). These studies provided three different datasets, consisting of: 1) population-level haplotype datasets for the mitochondrial cytochrome b (cytb; Strecker et al., 2004) and NADH dehydrogenase 2 (ND2; Dowling et al., 2002a) genes, and 2) a species-level dataset of four nuclear (recombination activating gene - RAG2; seven in absentia - sina; forkhead - fkh; and $\alpha$-tropomyosin - trop) and two mitochondrial genes (16S rDNA and cytb) from representatives within the Otophysi (Calcagnotto et al., 2005). Divergence times from all three data sets were estimated and compared.

\section{Species-level Phylogenetic Analyses}

The species-level dataset included selected Otophysi, Characiformes, and Characidae sequences (see Tab. 1), and was analyzed using Anotophysi species as outgroups. Representative $A$. mexicanus cyt $b$ haplotype sequences from the Strecker et al., (2004) study were included in the dataset of characiform species to estimate divergence times based on fossil calibrations for comparison with population-based estimates utilizing substitution rates. Alignments of protein-coding regions were trivial and were accomplished using amino acid translations. Sequences of the trop gene spanned an intron, which was removed due to significant length variation (70-836 bp) leading to ambiguous alignments. The alignment of the 16s rDNA gene was generated using the E-INS-i accuracy-oriented strategy of MAFFT v.5 (Katoh et al., 2005). All of the individually aligned genes were then concatenated to form a single dataset consisting 3770bp in length. The concatenated dataset was analyzed with PAUP $^{\star} 4.0 \mathrm{~b} 10$ (Swofford, 2000) using maximum parsimony and implementing the parsimony ratchet method (Nixon, 1999) using a batch file generated by PAUPRat with the default parameters for 5000 replicates (Sikes \& Lewis, 2001).

\section{Divergence time estimation}

Population analysis. Dates of divergence were inferred for A. mexicanus lineage $A$ and $B$ cave fish populations using the cyt $b$ and ND2 datasets with BEASTv1.4 (Drummond \& Rambaut, 2003). Because the cytb and ND2 haplotype datasets were generated from different studies, they cannot be combined. Therefore, each dataset was used to independently estimate the divergence times of the $A$. mexicanus cave-adapted haplotype sequences. Each dataset was analyzed using both strict and relaxed clock models (Drummond et al., 2006) tested under constant and skyline models of population growth. As part of BEAST divergence time estimation, either a calibration point (fossil or geologic) or a gene-specific substitution rate is required. Because there are no geologic dates corresponding to $A$. mexicanus populations invading subterranean systems, substitution rates were used. For each gene, the range of substitution rates calculated for other freshwater fish were used. For cytb, mean substitution rates ranged from 0.005 to 0.017 substitutions/site/million year (my) (Bermingham et al., 1997; Burridge et al., 2006; Dowling et al., 2002b; Perdices \& Doadrio, 2001; Sivasundar et al., 2001; Zardoya \& Doadrio, 1999) and for ND2 mean substitution rates ranged from 0.011 to 0.026 substitutions/site/my (Near et al., 2003; Mateos, 2005). These independent rates were used to calibrate the rate of evolution of our datasets by either fixing the rate to the lowest and highest value estimated for each gene or using strong prior distributions on the substitution rates. Two independent MCMC analyses $2 \times 10^{7}$ steps long were performed sampling every $2,000^{\text {th }}$ generation, with a burn-in of $2 \times 10^{6}$ generations. All the Bayesian MCMC output generated by BEAST was analyzed in Tracer v1.3 (Drummond \& Rambaut, 2003).

Likelihood-based AHRS method. We used the likelihood heuristic rate-smoothing algorithm of (Yang, 2004) as implemented in PAML3.14 (Yang, 2001). Sequence data were analyzed using the F $84+\Gamma$ model. Branches at each locus were classified into four rate groups according to their estimated rates. The oldest known fossil representatives of major lineages within the Ostariophysi are well established in recent literature (see Briggs, 2005 and references therein), and have been used in recent studies estimating molecular-based divergence times of Otocephalan clades (Peng et al., 2006). These fossil representatives were used as calibration points for the AHRS divergence time analysis (Fig. 1, Tab. 2,). Fossil calibrations were accommodated as fixed ages and mapped to the basal node of the clade of interest. Given that most fossils are dated to an age range, the minimum and maximum ages of each fossil were used for divergence time estimations under separate analyses. Fossil dates were determined using the 1999 GSA Geologic Time Scale. 
Tab. 1: Taxonomy, gene data, and Genbank accession numbers for sequences used in Characiformes phylogeny reconstruction. Abbreviations of mitochondrial gene sequences: $16 \mathrm{~S}=16 \mathrm{~S} r \mathrm{DNA}$, cytb=cytochrome $b$; abbreviations for nuclear gene sequences: fkh = forkhead, RAG2 = recombination activating gene, sina $=$ seven in absentia, trop $=\alpha$-tropomyosin.

\begin{tabular}{|c|c|c|c|c|c|c|}
\hline & $16 S$ & cytb & fkh & RAG2 & sina & trop \\
\hline \multicolumn{7}{|l|}{ Anotophysi (outgroup) } \\
\hline \multicolumn{7}{|l|}{ Chanidae } \\
\hline $\begin{array}{l}\text { Chanos chanos } \\
\text { Gonorynchidae }\end{array}$ & NC004693 & NC004693 & --- & --- & --- & --- \\
\hline $\begin{array}{l}\text { Gonorynchus greyi } \\
\text { Kneriidae }\end{array}$ & NC004702 & NC004702 & --- & --- & --- & --- \\
\hline Cromeria nilotica & NC007881 & NC007881 & --- & --- & --- & --- \\
\hline Parakneria cameronensis & NC007891 & NC007891 & --- & --- & --- & --- \\
\hline \multicolumn{7}{|l|}{ Otophysi (ingroup) } \\
\hline \multicolumn{7}{|l|}{ CHARACIFORMES } \\
\hline \multicolumn{7}{|l|}{ Anostomidae } \\
\hline $\begin{array}{l}\text { Leporinus sp. } \\
\text { Chilodontidae }\end{array}$ & AY788044 & AY791416 & AY817370 & AY804095 & AY790102 & AY817252 \\
\hline $\begin{array}{l}\text { Chilodus punctatus } \\
\text { Prochilodontidae }\end{array}$ & AY787997 & --- & AY817325 & --- & AY790056 & AY817215 \\
\hline $\begin{array}{l}\text { Prochilodus nigricans } \\
\text { Hemiodontidae }\end{array}$ & AY788075 & AY791437 & AY817400 & AY804120 & AY790133 & AY817278 \\
\hline $\begin{array}{l}\text { Hemiodus gracilis } \\
\text { Parodontidae }\end{array}$ & AY788027 & AY791405 & AY817353 & AY804084 & AY790086 & AY817240 \\
\hline $\begin{array}{l}\text { Parodon sp. } \\
\text { Serrasalmidae }\end{array}$ & AY788065 & AY791427 & AY817390 & AY804110 & AY790123 & AY817269 \\
\hline $\begin{array}{l}\text { Colossoma macropomum } \\
\text { Cynodontidae }\end{array}$ & AY788000 & AY791386 & AY817328 & AY804061 & AY790059 & AY817218 \\
\hline $\begin{array}{l}\text { Hydrolycus pectoralis } \\
\text { Characidae }\end{array}$ & AY788033 & --- & AY817359 & AY804088 & AY790091 & AY817244 \\
\hline Acestrorhynchus sp. & AY787956 & AY791353 & AY817288 & AY804026 & AY790014 & AY817181 \\
\hline Aphyocheirodon sp. & AY787966 & AY791363 & AY817298 & AY804031 & AY790025 & --- \\
\hline Astyanacinus sp. 1 & AY787969 & AY791365 & AY817301 & AY804033 & AY790028 & AY817190 \\
\hline Astyanacinus sp.2 & AY787987 & --- & AY817317 & AY804051 & AY790046 & AY817209 \\
\hline Astyanax bimaculatus & AY787955 & --- & AY817287 & AY804025 & AY790013 & AY817180 \\
\hline Astyanax mexicanus (Brazil) & --- & AY177206 & --- & --- & --- & --- \\
\hline Astyanax mexicanus (haplotype $\mathrm{AB}$ ) & -- & AY639041 & -- & -- & -- & -- \\
\hline Astyanax mexicanus (haplotype AL) & -- & AY639051 & -- & -- & -- & -- \\
\hline Astyanax mexicanus (haplotype EA) & -- & AY639075 & -- & -- & -- & -- \\
\hline Astyanax mexicanus (haplotype FA) & -- & AY639084 & -- & -- & -- & -- \\
\hline Astyanax mexicanus (haplotype GA) & -- & AY639089 & -- & -- & -- & -- \\
\hline Astyanax mexicanus (haplotype GB) & -- & AY639090 & -- & -- & -- & -- \\
\hline Astyanax scabripinis & AY787967 & --- & AY817299 & --- & AY790026 & AY817188 \\
\hline Brycon hilarii & AY787976 & AY791370 & AY817307 & AY804040 & AY790035 & AY817198 \\
\hline Bryconamericus diaphanus & AY787984 & AY791375 & AY817314 & AY804048 & AY790043 & AY817206 \\
\hline Bryconops sp. & AY787985 & AY791376 & AY817315 & AY804049 & AY790044 & AY817207 \\
\hline Chalceus erythrurus & AY787990 & AY791379 & AY817320 & AY804053 & AY790049 & AY817211 \\
\hline Chalceus macrolepidotus & AY787999 & AY791385 & AY817327 & AY804060 & AY790058 & AY817217 \\
\hline Cheirodon sp. & AY787995 & AY791382 & AY817324 & AY804057 & AY790054 & --- \\
\hline Cheirodontops sp. & AY787996 & AY791383 & --- & AY804058 & AY790055 & --- \\
\hline Creagrutus sp. & AY788001 & --- & --- & AY804062 & AY790060 & AY817219 \\
\hline Exodon paradoxus & AY788013 & AY791397 & AY817340 & AY804072 & AY790072 & AY817227 \\
\hline Gephyrocharax sp. & AY788014 & AY791398 & AY817341 & AY804073 & AY790073 & AY817228 \\
\hline Hemibrycon beni & AY788020 & AY791402 & AY817346 & AY804079 & AY790079 & AY817234 \\
\hline Hemigrammus bleheri & AY788017 & -- & AY817343 & AY804076 & AY790076 & AY817231 \\
\hline
\end{tabular}




\begin{tabular}{|c|c|c|c|c|c|c|}
\hline & $16 S$ & cytb & fkh & RAG2 & sina & trop \\
\hline Hemigrammus erythrozonus & AY788023 & --- & AY817349 & AY804081 & AY790082 & AY817236 \\
\hline Hemigrammus rodwayi & AY788034 & --- & AY817360 & AY804089 & AY790092 & AY817245 \\
\hline Hyphessobrycon eques & AY788022 & --- & AY817348 & AY804080 & AY790081 & AY817235 \\
\hline Inpaichthys kerri & AY788039 & --- & AY817365 & AY804093 & AY790097 & AY817248 \\
\hline Knodus sp. & AY788041 & AY791414 & AY817367 & AY804094 & AY790099 & AY817249 \\
\hline Moenkhausia sanctaphilomenae & AY788054 & --- & --- & AY804104 & AY790112 & AY817261 \\
\hline Mimagoniates lateralis & AY788051 & AY791420 & AY817377 & AY804101 & AY790109 & AY817259 \\
\hline Prodontocharax sp. & AY788064 & AY791426 & AY817389 & AY804109 & AY790122 & --- \\
\hline Roeboides sp. & AY787994 & AY791381 & AY817323 & AY804056 & AY790053 & AY817214 \\
\hline Salminus maxillosus & AY788080 & AY791438 & AY817405 & AY804124 & AY790137 & AY817282 \\
\hline $\begin{array}{l}\text { Triportheus angulatus } \\
\text { Ctenolucidae }\end{array}$ & AY788082 & --- & AY817407 & AY804125 & AY790139 & AY817283 \\
\hline $\begin{array}{l}\text { Ctenolucius hujeta } \\
\text { Lebiasinidae }\end{array}$ & AY787998 & AY791384 & AY817326 & AY804059 & AY790057 & AY817216 \\
\hline $\begin{array}{l}\text { Nannostomus beckfordi } \\
\text { Crenuchidae }\end{array}$ & AY788059 & --- & AY817384 & --- & AY790117 & AY817265 \\
\hline $\begin{array}{l}\text { Characidium fasciatum } \\
\text { Erythrinidae }\end{array}$ & AY787992 & AY791380 & AY817322 & AY804055 & AY790051 & AY817213 \\
\hline $\begin{array}{l}\text { Hoplias sp. } \\
\text { Alestidae }\end{array}$ & AY788031 & AY791409 & AY817357 & AY804087 & AY790090 & AY817242 \\
\hline Arnoldichthys spilopterus & AY787968 & AY791364 & AY817300 & AY804032 & AY790027 & AY817189 \\
\hline Brycinus nurse & AY787970 & AY791366 & AY817302 & AY804034 & AY790029 & AY817191 \\
\hline $\begin{array}{l}\text { Phenacogrammus aurantiacus } \\
\text { Hepsetidae }\end{array}$ & AY788066 & AY791428 & AY817391 & AY804111 & AY790124 & AY817270 \\
\hline $\begin{array}{l}\text { Hepsetus odoe } \\
\text { Citharinidae }\end{array}$ & AY788030 & AY791408 & AY817356 & AY804086 & AY790089 & AY817241 \\
\hline $\begin{array}{l}\text { Citharinus citharus } \\
\text { Distichodontidae }\end{array}$ & AY787989 & AY791378 & AY817319 & --- & AY790048 & --- \\
\hline Distichodus sexfasciatus & AY788012 & AY791396 & AY817339 & AY804071 & AY790071 & AY817226 \\
\hline Neolebias trilineatus & AY788063 & AY791425 & AY817388 & AY804108 & AY790121 & AY817268 \\
\hline $\begin{array}{l}\text { CYPRINIFORMES } \\
\text { Cobitidae }\end{array}$ & & & & & & \\
\hline $\begin{array}{l}\text { Misgurnus sp. } \\
\text { Cyprinidae }\end{array}$ & AY788053 & --- & AY817379 & AY804103 & AY790111 & --- \\
\hline Danio rerio & AY788011 & --- & AY817338 & AY804070 & AY790070 & AY817225 \\
\hline $\begin{array}{l}\text { Labeo sorex } \\
\text { Gyrinocheilidae }\end{array}$ & AY788043 & AY791415 & AY817369 & --- & AY790101 & AY817251 \\
\hline Gyrinocheilus sp. & AY788015 & AY791399 & --- & AY804074 & AY790074 & AY817229 \\
\hline $\begin{array}{l}\text { SILURIFORMES } \\
\text { Callichthyidae }\end{array}$ & & & & & & \\
\hline $\begin{array}{l}\text { Corydoras rabauti } \\
\text { Loricariidae }\end{array}$ & NC004698 & NC004698 & --- & --- & --- & --- \\
\hline $\begin{array}{l}\text { Ancistrus sp. } \\
\text { Bagridae }\end{array}$ & AY787958 & AY791354 & AY817290 & --- & AY790016 & AY817183 \\
\hline $\begin{array}{l}\text { Chrysichthys sp. } \\
\text { Heptapteridae }\end{array}$ & AY787957 & AY791355 & --- & --- & AY790017 & AY817193 \\
\hline $\begin{array}{l}\text { Pimelodella sp. } \\
\text { Ictaluridae }\end{array}$ & AY787953 & AY791351 & AY817285 & --- & AY790011 & AY817178 \\
\hline Ictalurus punctatus & AY788040 & AY791413 & AY817366 & --- & AY790098 & --- \\
\hline
\end{tabular}




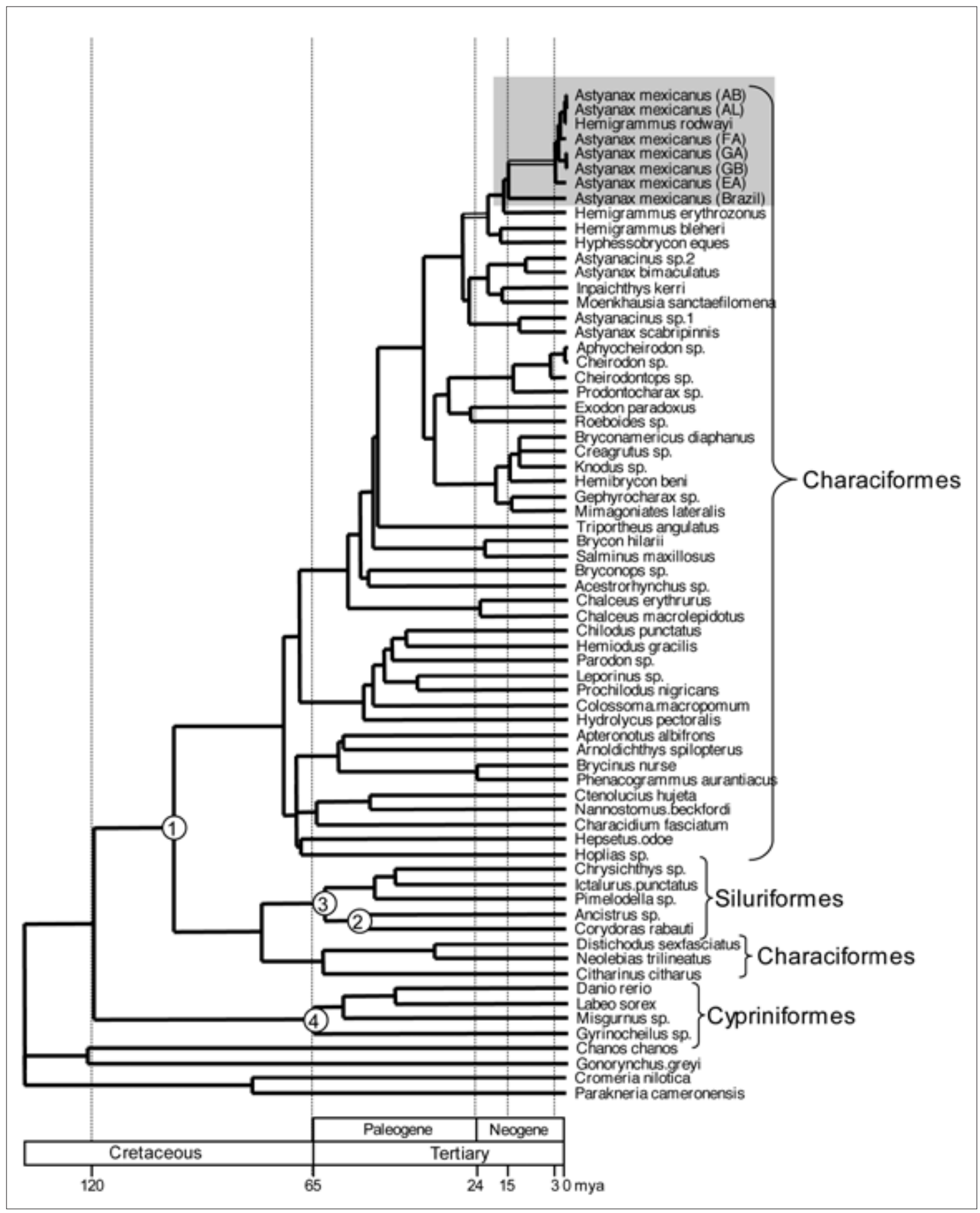

Fig. 1: Characiform divergence time chronogram estimated using a representative topology chosen from the set of 867 most parsimonious trees. White branches indicate branches where less than 75\% of the most parsimonious trees were topologically congruent. The grey box indicates the clade of Astyanax mexicanus sequences. Fossil calibration nodes are numbered and correspond to Tab. 2. The major geologic periods are mapped onto the phylogeny. 
Tab. 2: Taxonomy and ages of fossils used as calibrations for divergence time estimation. Node \# refers to Fig. 1.

\begin{tabular}{lllc}
\hline Taxonomy & Reference & Geologic age (MYA) & Node \# \\
\hline $\begin{array}{l}\text { Otophysi } \\
\text { Characiformes }\end{array}$ & Gayet, 1982 & Late Cretaceous (65-99) & 1 \\
Cypriniformes & & & \\
Catostomidae & Cavender, 1986 & Paleocene (54.8-65) & 4 \\
Siluriformes & Gayet \& Meunier, 2003 & late Campanian-early Maastrichtian (68.2-77.4) & 3 \\
Corydoras & Cockerell, 1925 & Late Palaeocene (61-65) & 2 \\
\hline
\end{tabular}

\section{RESULTS}

Population-level divergence time estimations. Estimates of the mean divergence times were not significantly different between strict and relaxed clock and population growth models and calibration methods of the substitution rate, but confidence intervals under the fixed substitution rate approach were narrower, as expected. Hence only the time estimates under the strict clock model, constant population size and minimum and maximum mean substitution rates for both genes are provided. Comparing the cytb and ND2 estimates of divergence times for the A. mexicanus A and B lineages show several features. First, the estimated ranges of divergence for cave haplotypes within each lineage were similar between genes (cytb and ND2) and lineages (A and B), placing the divergence among hypogean populations between 0.141 0.885 Ma for lineage A, and 0.084-0.575 Ma for lineage $\mathrm{B}$ (Tab. 3). When comparing the estimates among genes within a lineage, however, the divergence times of hypogean and epigean haplotypes are different, with cytb estimates providing generally older estimates.

Species-level divergence time estimation. Using the maximum parsimony ratchet, the selected Characidae,
Characiform, and Otophysi sequences generated 867 trees of score 11758 . The $50 \%$ majority rule consensus of these trees was similar to the published research that generated the data (Calcagnotto et al., 2005). Because a fully resolved tree with branch lengths is required for AHRS divergence time estimation and because very few branches in the consensus tree collapsed (e.g. were in conflict), a random tree from the set of 867 was used (Fig. 1). The A. mexicanus sequences included in the analysis clustered with other Characidae species, although were not monophyletic with other Astyanax species (A. bimaculatus and A. scabripinnis). The divergence time estimates for the representative $A$. mexicanus cave fish populations generated using this phylogeny with Otophysi fossil calibrations agreed well with the estimates of hypogean haplotype divergence from cyt $b$ and ND2 using substitution rates (Tab. 3). However, the estimates of cave versus surface population divergence times based on fossil calibrations were in better agreement with ND2 than with cytb estimates. This is particularly interesting, as the only gene included in this dataset for A. mexicanus was cyt $b$.

Tab. 3: Comparison of divergence time estimates using substitution rates and molecular clock methods for cytochrome $b$ (cytb) and NADH dehydrogenase 2 (ND2) mitochondrial genes, and for molecular methods incorporating fossil dates as calibrations.

\begin{tabular}{|c|c|c|c|}
\hline & \multicolumn{2}{|c|}{ Substitution Rates } & \multirow[t]{2}{*}{ Fossil Calibration } \\
\hline & Cytb & ND2 & \\
\hline & $\operatorname{Min}-\operatorname{Max}(\mathrm{Ma})$ & Min - Max (Ma) & Min - Max (Ma) \\
\hline \multicolumn{4}{|l|}{ Lineage A } \\
\hline cave & $0.261-0.885$ & $0.141-0.331$ & $0.2-0.3$ \\
\hline cave vs. surface & $0.588-2.00$ & $0.256-0.599$ & $0.4-0.5$ \\
\hline \multicolumn{4}{|l|}{ Lineage B } \\
\hline cave & $0.169-0.575$ & $0.084-0.196$ & $0.1-0.1$ \\
\hline cave vs. surface & $1.524-5.181$ & $0.877-2.055$ & $1.7-2.2$ \\
\hline Lineage A vs. Lineage B & $1.741-5.922$ & $1.053-2.472$ & $1.7-2.2$ \\
\hline
\end{tabular}




\section{DISCUSSION}

Previous molecular studies of A. mexicanus phylogeography indicate that at least two independent invasions of surface Astyanax have occurred (Dowling et al., 2002a; Strecker et al., 2003, 2004). Our estimates of divergence time from two different methods and three different datasets are in general agreement about the divergence times among the cave haplotypes in each lineage (Tab. 3). These estimates place cave haplotype divergence times in the Pleistocene, when it is suggested that climatic cooling of surface waters led to the extinction of Astyanax in North America (Strecker et al., 2004). In particular, our data show an interesting pattern for lineage $B$ haplotypes, which are proposed to be the older of the two lineages. The recent divergence times estimated for lineage B haplotypes (0.084-0.575 Ma) supports the hypothesis that after the initial colonization event, subterranean routes of colonization were associated with fluctuating groundwater levels in the Pleistocene (Strecker et al., 2004). The fact that estimated times of within lineage divergence were similar also suggests that the divergence of subterranean haplotypes in both lineages were influenced by the same processes.

In order to determine the evolutionary age of the subterranean lineage, and therefore estimate the time required for evolution of the troglomorphic form, the divergence of the hypogean haplotypes from epigean populations is needed. However, the estimates from our three datasets did not agree, with cytb molecular clock methods estimating older divergence times than either ND2 or fossil calibrated estimates. Some of the discrepancy is due to the fact that different sets of surface populations were sampled in each study (Dowling et al., 2002a; Strecker et al., 2004). For example, the most closely related surface population in the cytb study were from Belize (Strecker et al., 2004) while there were no closely related surface populations to lineage B haplotypes in the ND2 study (Dowling et al., 2002a). However, this makes the older cytb estimates even more notable because lineage $B$ haplotypes have no evidence of introgressive hybridization with surface populations. If we consider just lineage B hypogean divergence from surface ancestors as an estimate of subterranean evolution, the estimated time for acquisition of the troglomorphic form is $0.877-2.055 \mathrm{Ma}$ (Quaternary - Tertiary boundary) based on ND2 and fossil calibrations, while it is 1.524-5.181 Ma (Pliocene) based on cytb.

Although the estimates of divergence times among the three different datasets did not agree, comparison of estimates between the lineages show that lineage A diverged from surface ancestors more recently than lineage B (Tab. 3). This more recent divergence from epigean populations is congruent with previous hypotheses, that either lineage A populations represent a more recent subterranean invasion, or that they are an older invasion masked by more recent mitochondrial introgressive hybridization with surface forms (Dowling et al., 2002a). In the few studies that have looked at other markers (allozymes, microsatellites, and RAPDs), it has been suggested that at least Chica and Pachón populations are the result of surface introgression (Avise \& Selander, 1972; Espinasa \& Borowsky, 2001; Strecker et al., 2003). Furthermore, based on the degree of variability in troglomorphic features of each lineage A population, it has been suggested that different populations represent different degrees and patterns of surface introgression. In order to more accurately determine both the patterns of introgression in the lineage A populations, as well as the underlying relationships of the cave populations to each other in order to estimate subterranean evolutionary times, studies investigating more types of markers are needed.

Previous research of $A$. mexicanus populations throughout Mexico (including cavefish lineages A and B) estimated haplotype divergences to range from $1.8-4.5$ $\mathrm{Ma}$ (Strecker et al., 2004). Our estimates suggest that divergence times among cave haplotypes and between lineage $\mathrm{A}$ cave and epigean haplotypes are much younger than this; however, hypogean divergences from surface ancestors in lineage B are concordant with these older dates.

The evolutionary history of cave adaptation in $A$. mexicanus is complex. Based on mitochondrial molecular clock estimates, our estimates of divergence times are congruent with previous hypotheses by showing lineage $\mathrm{B}$ to be a phylogenetically older subterranean lineage, with more recent divergence among subterranean systems. However, this study also provides quantitative dates for these events. Lineage A populations are estimated to be younger; however, these dates only represent mitochondrial lineages. Several of the populations in lineage A have been shown to be introgressed with surface forms (Chica, Pachón, and Subterraneo). To our knowledge, the hypothesis of surface introgression has not been investigated in the remaining lineage A populations (Molino, Pichijumo, and Yerbaniz). Understanding the patterns of introgression in all of the lineage A populations, and estimating the actual subterranean evolutionary time, requires investigating additional nuclear markers. 


\section{CONCLUSIONS}

Features including colonization routes (stream capture) and the existence of both epigean and cave-adapted hypogean populations make $A$. mexicanus an attractive system for investigating the subterranean evolutionary time necessary for acquisition of the troglomorphic form. If it is possible to estimate the divergence time of closely related cave versus surface populations, we can estimate the age of subterranean occupancy. This same divergence time also has relevancy to geologic processes in the karst system by providing a rough estimate of the age of subterranean stream capture in particular regions. Based on published sequence data, we have estimated divergence times for three events in the evolutionary history of troglomorphic A. mexicanus populations. First, divergence times among cave haplotypes in both lineages occurred in the Pleistocene, possibly correlating with fluctuating water levels allowing the colonization, and subsequent isolation of, new subterranean habitats. Second, in lineage A, A. mexicanus cave populations experienced introgressive hybridization events with surface populations recently. Finally, using divergence times of lineage $B$ from surface populations as an estimate, the acquisition of the troglomorphic form in A. mexicanus is younger than 2.2 (fossil calibration) - 5.2 (cytb) Ma (Pliocene). Given that there are at least 30 caves known to contain populations of $A$. mexicanus (Espinasa et al., 2001; Mitchell et al., 1977), the number of independent invasions and instances of introgressive hybridization may be even higher than currently understood. In order to fully understand the number of independent invasions, the history of introgression with surface populations, and the divergence times of cave and surface populations, a broader survey of cave fish populations and of both nuclear and mitochondrial markers is needed.

\section{LITERATURE CITED}

Aden, E., 2005: Adaptation to darkness. In Culver, D.C., \& White, W.B., (eds.), Encyclopedia of Caves, Elsevier Academic Press, pp.1-3.

Avise, J.C., \& R.K. Selander., 1972: Genetics of cavedwelling fishes of the genus Astyanax. -Evolution, 26, 1-19.

Bermingham, E., McCafferty, S.S., \& A.P. Martin., 1999: Fish biogeography and molecular clocks: perspectives from the Panamanian isthmus. In Kocher, T.D., \& Stepien, C.A., (eds.), Molecular systematics of fishes. Academic Press, San Diego, CA. pp.113-128.

Briggs, J.C., 2005: The biogeography of otophysan fishes (Ostariophysi: Otophysi): a new appraisal. -Journal of Biogeography, 32, 287-294.

Burridge, C.P., Craw, D., \& J.M. Waters., 2006: River capture, range expansion, and cladogenesis: The genetic signature of freshwater vicariance. -Evolution, 60, 1038-1049.

Calcagnotto, D., Schaefer, S.A., \& R. DeSalle., 2005: Relationships among characiform fishes inferred from analysis of nuclear and mitochondrial gene sequences. -Molecular and Phylogenetics and Evolution, 36, 135-153.

Cavender, T.M., 1986: Review of the fossil history of North American freshwater fishes. In Hocutt, C.H., \& Wiley, E.O. (eds.), The zoogeography of North American freshwater fishes. John Wiley, New York, pp.699-724.
Cockerell, T.D., 1925: A fossil fish of the family Callichthyidae. -Science, 62, 317-322.

Culver, D.C., Kane, T.C., \& D.W. Fong., 1995: Adaptation and natural selection in caves. Harvard University Press, Cambridge, 223p.

Dowling, T.E., Martasian, D.P., \& W.R. Jeffery., 2002a: Evidence for multiple genetic forms with similar eyeless phenotypes in the blind cavefish, Astyanax mexicanus. -Molecular Biology and Evolution, 19, 446-455.

Dowling, T.E., Tibbets, C.A., Minckley, W.L., \& G.R. Smith, 2002b: Evolutionary relationships of the plagopterins (Teleostei: Cyprinidae) from cytochrome b sequences. -Copeia, 2002, 665-678.

Drummond, A.J., \& Rambaut, A., 2003: BEAST version 1.4 [computer program]. Available: http://evolve. zoo.ox.ac.uk/beast. Accessed 25 November 2006.

Drummond, A.J., Ho, S.Y.W., Phillips, M.J., \& A. Rambaut., 2006: Relaxed phylogenetics and dating with confidence. -PLoS Biology 4, e88.

Espinasa, L., \& R.B. Borowsky., 2001: Origins and relationship of cave populations of the blind Mexican tetra, Astyanax fasciatus, in the Sierra de El Abra. -Environmental Biology of Fishes, 62, 233-237.

Espinasa, L., Rivas-Manzano, P., \& H. Espinosa-Pérez., 2001: A new blind cave fish population of the genus Astyanax: geography, morphology and behavior. -Environmental Biology of Fishes, 62, 339-344. 
Gayet, M., 1982: Consideration sur la phylogenie et la paleobiographie des Ostariophysaries. -Geobios Memoir, 6, 39-52.

Gayet, M., \& F.J. Meunier., 2003: Palaeontology and palaeobiogeography of catfishes. In Arratia, G., Kapoor, B.G., Chardon, M., \& Diogo, R., (eds.), Catfishes, Vol. 2, pp.491-522. Science Publishes, Enfield, NH.

Hubbs, C.L., \& W.T. Innes., 1936: The first known blind fish of the family Characidae: A new genus from Mexico. -Occasional Papers of the Museum of Zoology University of Michigan, 342, 1-7.

Jeffery, W.R., 2001: Cavefish as a model system in evolutionary developmental biology. -Developmental Biology, 231, 1-12.

Jeffery, W.R., 2005: Adaptive evolution of eye degeneration in the Mexican blind cavefish. -Journal of Heredity, 96, 185-196.

Katoh, K., Kuma, K., Toh, H., \& T.Miyata., 2005: MAFFT version 5: improvement in accuracy of multiple sequence alignment. -Nucleic Acids Research, 33, 511-518.

Mateos, M., 2005: Comparative phylogeography of livebearing fishes in the genera Poeciliopsis and Poecilia (Poeciliidae: Cyprinodontiformes) in central Mexico. -Journal of Biogeography, 32, 775-780.

Mitchell, R.W., Russell, W.H., \& W.R. Elliott., 1977: Mexican eyeless characin fishes, Genus Astyanax: environment, distribution, and evolution. Texas Tech University Special Publications of the Museum, 12, 89pp.

Near, T.J., Kassler, T.W., Koppelman, J.B., Dillman, C.B., \& D.P. Philipp., 2003: Speciation in North American black basses, Micropterus (Actinopterygii: Centrarchidae). -Evolution, 57, 1610-1621.

Nixon, K.C., 1999: The Parsimony Ratchet, a new method for rapid parsimony analysis. -Cladistics, 15, 407-414.

Peng, Z., He, S., Wang, J., Wang, W., \& R. Diogo., 2006: Mitochondrial molecular clocks and the origin of the major Otocephalan clades (Pisces: Teleostei): A new insight. -Gene, 370, 113-124.
Perdices, A., \& I. Doadrio., 2001: The molecular systematics and biogeography of the European cobitids based on mitochondrial DNA sequences. -Molecular Phylogenetics and Evolution, 19, 468-478.

Sikes, D.S., \& P.O. Lewis., 2001: Beta software, version 1. PAUPRat: PAUP* implementation of the parsimony ratchet. [computer program]. Available: http:// www.ucalgary.ca/ dsikes/software2.htm. Accessed 25 November 2006.

Sivasundar, A., Bermingham, E., \& G. Ortí., 2001: Population structure and biogeography of migratory freshwater fishes (Prochilodus: Characiformes) in major South American rivers. -Molecular Ecology, 10, 407-417.

Strecker, U., Bernatchez, L., \& H. Wilkens., 2003: Genetic divergence between cave and surface populations of Astyanax in Mexico (Characidae, Teleostei). -Molecular Ecology, 12, 699-710.

Strecker, U., Faúndez, V.H., \& H. Wilkens., 2004: Phylogeography of surface and cave Astyanax (Teleostei) from Central and North America based on cytochrome b sequence data. -Molecular Phylogenetics and Evolution, 33, 469-481.

Swofford, D.L., 2000: PAUP* ${ }^{\star}$ Phylogenetic analysis using parsimony (*and other methods). Version 4. Sinauer Associates, Sunderland, MA.

Wiley, S. \& R.W. Mitchell., 1971: A bibliography of the Mexican eyeless characin fishes of the genus Astyanax. -Association for Mexican Studies Bulletin, 4, 231-239.

Yang, Z., 2001: PAML: Phylogenetic Analysis by Maximum Likelihood. University College London, London.

Yang, Z., 2004: A heuristic rate smoothing procedure for maximum likelihood estimation of species divergence times. -Acta Zoologica Sinica, 50, 645-656.

Zardoya, R., \& I. Doadrio., 1999: Molecular evidence on the evolutionary and biogeographical patterns of European cyprinids. -Journal of Molecular Evolution, 49, 227-237. 